\title{
Dopamine Decreases Expression of Type-1 Angiotensin II Receptors in Renal Proximal Tubule
}

\author{
Hui-Fang Cheng, Bryan N. Becker, and Raymond C. Harris \\ Department of Medicine, Vanderbilt University School of Medicine and the Department of Veterans Affairs Medical Center, Nashville, \\ Tennessee 37232
}

\begin{abstract}
Systemic and/or locally produced angiotensin II stimulates salt and water reabsorption in the renal proximal tubule. In vivo, dopamine (DA) may serve as a counterregulatory hormone to angiotensin II's acute actions on the proximal tubule. We examined whether dopamine modulates $\mathrm{AT}_{1}$ receptor expression in cultured proximal tubule cells (RPTC) expressing $\mathrm{DA}_{1}$ receptors. Dopamine decreased basal RPTC $\mathrm{AT}_{1}$ receptor mRNA levels by $67 \pm 7 \%(n=10 ; P<0.005)$ and decreased ${ }^{125} \mathrm{I}$-angiotensin II binding by $41 \pm 7 \%(n=4$; $P<0.05)$. The $\mathrm{DA}_{1}$-specific agonist, SKF38393 decreased basal $\mathrm{AT}_{1}$ receptor mRNA levels $(65 \pm 5 \%$ inhibition; $n=5$; $P<0.025$ ), and the $\mathrm{DA}_{1}$-specific antagonist, $\mathrm{SCH} 23390$ reversed dopamine's inhibition of $\mathrm{AT}_{1}$ receptor mRNA expression (24 $\pm 10 \%$ inhibition; $n=8$; NS) and angiotensin II binding ( $5 \pm 15 \% ; n=4$; NS). $\mathrm{DA}_{2}$-specific antagonists were ineffective. In rats given L-DOPA in the drinking water for $5 \mathrm{~d}$, there were decreases in both proximal tubule $\mathrm{AT}_{1}$ receptor mRNA expression $(80 \pm 5 \% ; n=6 ; P<0.005)$ and specific $\left[{ }^{125} \mathrm{I}\right]$ Ang II binding (control: $0.74 \pm 0.13 \mathrm{fmol} / \mathrm{mg}$ pro vs. $0.40 \pm 0.63 \mathrm{fmol} / \mathrm{mg}$ pro; $n=5 ; P<0.05$ ).

In summary, dopamine, acting through $\mathrm{DA}_{1}$ receptors, decreased $\mathrm{AT}_{1}$ receptor expression in proximal tubule, an effect likely mediated by increased intracellular cAMP levels. Local dopamine production also led to decreased $\mathrm{AT}_{1}$ receptor expression, suggesting dopamine may reset sensitivity of the proximal tubule to angiotensin II. (J. Clin. Invest. 1996. 97:2745-2752.) Key words: angiotensin II • receptor • dopamine $\bullet$ kidney $\bullet$ proximal tubule $\bullet$ L-DOPA
\end{abstract}

\section{Introduction}

The proximal tubule is a major site of salt and water reabsorption in the mammalian nephron, with up to $60 \%$ of the filtrate reabsorbed in this segment. Proximal tubule function is under hormonal control, with the vasoconstrictor angiotensin II stimulating reabsorption and the vasodilator dopamine inhibiting reabsorption $(1,2)$.

Proximal tubule angiotensin II (Ang II $)^{1}$ binding sites are

Address correspondence to R.C. Harris, Division of Nephrology, Vanderbilt University School of Medicine, S-3223 Medical Center North, Nashville, TN 37232. Phone: 615-343-0030; FAX: 615-3437156.

Received for publication 13 December 1995 and accepted in revised form 28 March 1996.

1. Abbreviations used in this paper: ANG II, angiotensin II; RPTC, rabbit proximal tubule cells.

The Journal of Clinical Investigation

Volume 97, Number 12, June 1996, 2745-2752 present on both apical and basolateral membranes $(3,4)$. Ang II exerts direct effects on proximal tubule transport, independent of alterations in renal or systemic hemodynamics (5-7). We have previously demonstrated that ${ }^{125} \mathrm{I}$-Ang II binding to both basolateral and brush border membranes from either rat or rabbit is inhibited by losartan, indicating the presence of type 1 angiotensin II receptors ( $\mathrm{AT}_{1}$ receptors) on both membranes (8). Other studies have indicated that $\mathrm{AT}_{1}$ receptors mediate Ang II-mediated increases in proximal tubule volume reabsorption (9).

Previous studies have indicated that dopamine and Ang II serve counteracting functions in the proximal tubule $(2,10$, 11). Ang II stimulates net reabsorption via activation of apical $\mathrm{Na}^{+} / \mathrm{H}^{+}$exchange and basolateral $\left[\mathrm{Na}^{+}\right] /\left[\mathrm{K}^{+}\right]$ATPase, while dopamine inhibits the activity of these two transporters (12, 13). Furthermore, dopamine inhibits the Ang II-mediated activation of these transporters and Ang II-mediated proximal tubule reabsorption $(2,12)$. Since alterations in the balance of responsiveness of proximal tubule to angiotensin II and dopamine have important implications for net sodium and water reabsorption and have been implicated in genetic models of hypertension (14), the present studies examined the possibility dopamine may chronically regulate proximal tubule responsiveness to angiotensin II by decreasing $\mathrm{AT}_{1}$ receptor expression.

\section{Methods}

Materials. ${ }^{125} \mathrm{I}$-Ang II, ${ }^{125} \mathrm{I}-\mathrm{SCH} 23390$ and ${ }^{125} \mathrm{I}-\mathrm{CAMP}$ radioassay kit were from New England Nuclear (Boston, MA). ${ }^{32} \mathrm{P}-\mathrm{CTP}(3,000 \mathrm{Ci} /$ mmol) was from Amersham (Arlington Heights, IL). SCH23390, SKF38393, L-DOPA, dopamine, carbidopa, spiperone, and octoclothepin were from Research Biochemicals International (Natick, MA). Dideoxyadenosine and dibutyrl cAMP were from Calbiochem (La Jolla, CA).

Animals. Male Sprague-Dawley rats, weighing 150-250 grams were given L-3,4 Dihydroxyphenylalanine (L-DOPA) $(2 \mathrm{mg} / \mathrm{kg}$ per day) in the drinking water for $5 \mathrm{~d}(15)$. Age and weight matched rats were used as controls. The tail-cuff microphonic manometer method was used to measure blood pressures (16).

Isolation of proximal tubules. Modification of the methods of $\mathrm{Vi}-$ nay et al. were used $(17,18)$. Briefly, renal cortices were gently minced and suspended in a solution containing $115 \mathrm{mM} \mathrm{NaCl}, 24 \mathrm{mM}$ $\mathrm{NaHCO}_{3}, 5 \mathrm{mM} \mathrm{KCl}, 1.5 \mathrm{mM} \mathrm{CaCl}, 10 \mathrm{mM} \mathrm{MgSO}$, $2.0 \mathrm{mM}$ $\mathrm{NaH}_{2} \mathrm{PO}_{4}, 10 \mathrm{mM}$ Hepes, $\mathrm{pH} 7.4$ (Buffer A), with the following additions: $5 \mathrm{mM}$ glucose, $1 \mathrm{mM}$ alanine, $0.03 \%$ collagenase (Sigma type I), and $0.01 \%$ soy bean trypsin inhibitor (Sigma Chemical Co., St. Louis, $\mathrm{MO}$ ), gassed with $95 \% \mathrm{O}_{2} / 5 \% \mathrm{CO}_{2}$ and maintained at $37^{\circ} \mathrm{C}$. The cortical suspension was incubated for $45 \mathrm{~min}$ and gently agitated on a rocking platform. The suspension was strained through a large sieve, centrifuged, and resuspended in oxygenated Buffer A, then washed and recentrifuged three times. The resulting pellet was mixed with $100 \mathrm{ml}$ of a $40 \%$ Percoll solution with the identical ionic composition as Buffer $\mathrm{A}$ and which had been previously gassed with $95 \% \mathrm{O}_{2} / 5 \%$ $\mathrm{CO}_{2}$ and chilled to $4^{\circ} \mathrm{C}$. The Percoll solution was centrifuged at 15,000 RPM for 30 min at $4^{\circ} \mathrm{C}$ in a Beckman $\mathrm{J} 2-21$ high-speed preparative centrifuge using a JA 17 rotor. After centrifugation, the tissue was 
separated into four distinct bands, as described by Vinay et al. (17). The lowermost band, which was enriched in proximal tubule segments, was collected.

Cell culture. A previously described line of SV-40 immortalized rabbit proximal tubule cells (RPTC) was used for the present studies (19). Cells were cultured and maintained in DME/F12 supplemented with $10 \%$ fetal bovine serum, penicillin $(100 \mathrm{U} / \mathrm{ml})$, and streptomycin $(100 \mu \mathrm{g} / \mathrm{ml})$ at $37^{\circ} \mathrm{C}$ in $95 \%$ air $/ 5 \% \mathrm{CO}_{2}$ atmosphere. Cells were made quiescent by incubation for $48 \mathrm{~h}$ in media without fetal bovine serum before administration of agonists. Experiments were performed on confluent cell monolayers of passages 20-30. Primary cultures of rabbit proximal tubule cells were prepared as previously described (20).

Quantitation of $A T_{1}$ receptor by polymerase chain reaction. Total RNA was isolated by the acid guanidinium thiocyanate-phenol-chloroform method (21). Quantitative PCR was performed as previously described for SV40 rabbit proximal tubule cells (19) and isolated rat proximal tubules (22). For PCR, total RNA $(10 \mu \mathrm{g})$ and cRNA of an $\mathrm{AT}_{1}$ receptor Msc1-Msc-1 deletion mutant $(100 \mathrm{pg})$ were mixed and reverse transcribed using murine reverse transcriptase (Pharmacia, First Strand cDNA Synthesis kit, Piscataway, NJ) and a primer specific for the $\mathrm{AT}_{1}$ receptor in a final reaction volume of $33 \mu \mathrm{l}$. The resultant single strand cDNA mixture was then amplified in a Perkin Elmer GeneAMP 9600 PCR System using Taq polymerase (Perkin Elmer/Cetus). The used primers were upstream sense primer $\left(5^{\prime}-\right.$ TACATATTTGTCATGATTCCT-3') and downstream anti-sense primer ( $3^{\prime}$-GTGAATATTTGGTGGGGAAC-5'). PCR was performed for 35 cycles at $95^{\circ} \mathrm{C}$ for $20 \mathrm{~s}, 55^{\circ} \mathrm{C}$ for $30 \mathrm{~s}$ and $72^{\circ} \mathrm{C}$ for $90 \mathrm{~s}$, followed by a $10-\mathrm{min}$ extension at $72^{\circ} \mathrm{C}$. Amplification of intact and mutant $\mathrm{AT}_{1}$ receptor mRNA by these primers gave 703- and 415-bp fragments, respectively. No amplification occurred in the absence of reverse transcription, indicating that genomic DNA was not being amplified. Preliminary studies indicated linearity of response for at least 40 cycles. Samples were routinely amplified in the presence of $\alpha-\left[{ }^{32} \mathrm{P}\right]$ CTP (NEN, Boston, MA; 3,000 Ci/mmol; $2 \mu \mathrm{Ci} / \mathrm{sample}$ ). For normalization, parallel samples measured amplification of $\beta$-actin, using the primers $\left(5^{\prime}\right.$ :AACCGCGAGAAGATGACCCAGATCATGTTT; and 3':AGCAGCCGTGGCCATCTCTTGCTCGAAGTC) (23). After gel chromatography on $4 \%$ agarose gels, the bands corresponding to the $\mathrm{AT}_{1}$ receptor, deletion fragment and $\beta$-actin were excised and counted by scintillation spectrometry. Results are represented as the ratio of intact and deletion fragment $\mathrm{AT}_{1}$ receptor mRNA amplified, normalized to the amount of amplified $\beta$-actin mRNA. This method provides a relative comparison of the amount of $\mathrm{AT}_{1}$ receptor mRNA present among the different experimental groups $(19,24)$.

${ }^{125}$ I-Angiotensin II binding. Binding studies were performed using ${ }^{125}$ I-labeled angiotensin II and unlabeled angiotensin II. Cells were made serum-free $12-16 \mathrm{~h}$ before study and exposed to the indicated agent every $8 \mathrm{~h}$ in the presence of ascorbic acid $(1 \mu \mathrm{M})$. Cells were washed in a solution of PBS supplemented with $0.1 \%$ bovine serum albumin three times, then exposed to ${ }^{125} \mathrm{I}$-Ang II in PBS- $0.1 \%$ albumin at $4^{\circ} \mathrm{C}$ for $4 \mathrm{~h}$, with or without the indicated concentration of unlabeled angiotensin II. After the appropriate incubation, cells were washed three times with PBS- $0.1 \%$ albumin and cell-associated radioactivity was determined after digestion with $0.05 \mathrm{M} \mathrm{NaOH}$. Binding studies on rat proximal tubule suspensions prepared by Percoll gradient centrifugation as described above were performed using previously described methods for ${ }^{125} \mathrm{I}$-Ang II to membrane preparations (19). Radioactivity was measured in a gamma counter (Beckman 5500B). Specific binding was determined by subtracting the non-specific binding component measured in the presence of $1 \mu \mathrm{M}$ unlabeled Ang II from total ${ }^{125} \mathrm{I}$-Ang II binding.

$D A_{1}$ receptor expression in SV40 RPTC. ${ }^{125} \mathrm{I}-\mathrm{SCH} 23390$ binding studies were performed upon RPTC incubated in serum-free media for $24-48 \mathrm{~h}$. The cells were washed three times with PBS- $0.1 \%$ albumin and incubated with ${ }^{125} \mathrm{I}-\mathrm{SCH} 23390(0.1 \mathrm{nM})$ and increasing concentrations of unlabeled $\mathrm{SCH} 23390$ for $40 \mathrm{~min}$ at $23^{\circ} \mathrm{C}$, then washed three times with ice-cold PBS- $0.1 \%$ albumin and lysed with $0.05 \mathrm{M}$ $\mathrm{NaOH}$. For determination of $\mathrm{DA}_{1}$ mRNA expression, PCR primers were used that represented the third and seventh transmembrane regions of the rat $\mathrm{DA}_{1}$ receptor: upstream primer- 5'ATGTGCTCTACGGCGTCCATT3'; downstream primer- 5'CCACACAAACACATCGAAGGT3'. Samples of total RNA from rat renal cortex, rabbit renal cortex and RPTC were subjected to reverse transcription and then cDNA was amplified for 30 cycles in the presence of the above primers at $94^{\circ} \mathrm{C}$ for $45 \mathrm{~s}, 58^{\circ} \mathrm{C}$ for $45 \mathrm{~s}$, and $72^{\circ} \mathrm{C}$ for $60 \mathrm{~s}$.

cAMP production. cAMP production was measured by radioimmunoassay as previously described (25).

Statistics. Results are presented as the means \pm SEM. Results of PCR experiments and ${ }^{125}$ I-Ang II binding to cultured proximal tubule cells were normalized as percentage of control. Statistical comparisons utilized ANOVA and the Bonferoni modification of Student's $t$ test, with $P<0.05$ indicating significance. For analysis of ${ }^{125} \mathrm{I}$-Ang II binding and ${ }^{125} \mathrm{I}-\mathrm{SCH} 23390$ binding, results were fit with the ligand binding program, Graph Pad Prism (San Diego, CA).

\section{Results}

To determine whether SV40 immortalized RPTC expressed a type 1 dopamine receptor $\left(\mathrm{DA}_{1}\right)$, specific ${ }^{125} \mathrm{I}-\mathrm{SCH} 23390$ binding was determined. $\mathrm{SCH} 23390$ is a competitive antagonist that binds specifically to $\mathrm{DA}_{1}$ receptors (26). As Fig. $1 A$ indicates, SV40 RPTC exhibited specific ${ }^{125} \mathrm{I}-\mathrm{SCH} 23390$ binding, with an apparent $K_{\mathrm{d}}$ of $7.52 \pm 0.06 \times 10^{-7} \mathrm{M}$ and an apparent $\mathrm{B}_{\max }$ of $228.4 \pm 43.2 \mathrm{fmol} / \mathrm{mg}$ protein. Spiperone, the $\mathrm{DA}_{2}$-specific antagonist, did not displace bound ${ }^{125} \mathrm{I}-\mathrm{SCH} 23390$. RT-

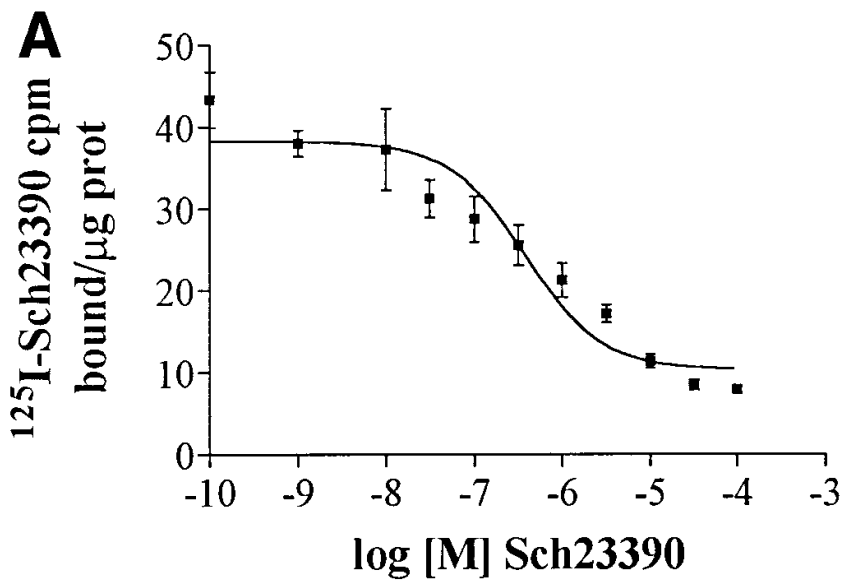

B

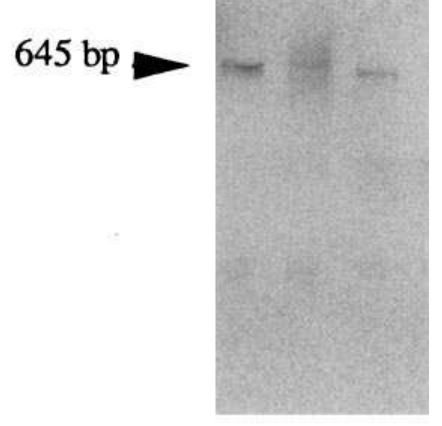

$\begin{array}{lll}1 & 2 & 3\end{array}$
Figure 1. (A) Specific ${ }^{125} \mathrm{I}-$ $\mathrm{SCH} 23390$ binding. Binding of $0.1 \mathrm{nM}^{125} \mathrm{I}-\mathrm{SCH} 23390$ in the presence of varying concentrations of unlabeled SCH23390 was determined as described in Methods. $\left(K_{\mathrm{d}}: 7.52 \pm 0.06 \times 10^{-7} \mathrm{M}\right.$; $B_{\max }: 228.4 \pm 43.2 \mathrm{fmol} / \mathrm{mg}$ protein; $n=6)(B)$ RT-PCR amplification of $\mathrm{DA}_{1} \mathrm{R}$ mRNA. Primers and PCR protocol were as described in Methods. Lane 1, rat renal cortex; lane 2, rabbit renal cortex; lane 3, SV40 immortalized rabbit proximal tubule cells. 
PCR further indicated the presence of $\mathrm{DA}_{1}$ receptor expression in RPTC using primers corresponding to third and seventh transmembrane regions of the rat $\mathrm{DA}_{1}$ receptor. As indicated, PCR amplification from total rat renal cortex RNA produced the expected 645-bp fragment and sequencing indicated its identity (Fig. $1 \mathrm{~B}$ ). Amplification of RNA from either rabbit kidney or RPTC produced DNA fragments of identical size, strongly suggesting the presence of a closely homologous $\mathrm{DA}_{1}$ receptor subtype.

Fig. 2 A provides a representative experiment indicating alterations in steady state $\mathrm{AT}_{1}$ receptor mRNA levels in response to agonist pretreatment. When RPTC were incubated with $10^{-5} \mathrm{M}$ dopamine for $4 \mathrm{~h}$, steady state $\mathrm{AT}_{1}$ receptor mRNA levels significantly decreased to $33 \pm 7$ of control levels (69 \pm 9 vs. $20 \pm 4 \mathrm{cpm} / \mathrm{cpm}$ of mutant $\mathrm{AT}_{1} \mathrm{R} / \mathrm{cpm} \beta$-actin $\times 10^{6}$; $n=10 ; P<0.005)$. $\mathrm{AT}_{1}$ receptor mRNA expression was decreased in a concentration dependent manner, with significant decreases seen at $\geq 10^{-6} \mathrm{M}$ and maximum inhibition noted at $10^{-5} \mathrm{M}$ (Fig. $2 \mathrm{~B}$ ). Similar decreases in $\mathrm{AT}_{1}$ receptor mRNA were noted in primary cultures of rabbit proximal tubule cells treated with dopamine ( $49 \pm 9$ vs. $15 \pm 3 \mathrm{cpm} / \mathrm{cpm}$ of mutant $\mathrm{AT}_{1} \mathrm{R} / \mathrm{cpm} \beta$-actin $\left.\times 10^{6} ; n=4 ; P<0.05\right)$.

In RPTC ${ }^{125}$ I-Ang II binding was similarly decreased in a concentration dependent manner (Fig. 2 C). Simultaneous incubation of angiotensin II $\left(10^{-9} \mathrm{M}\right)$ prevented the decreases in $\mathrm{AT}_{1}$ receptor mRNA seen with incubation with $10^{-5} \mathrm{M}$ dopamine (145 $\pm 43 \%$ of control; $n=8$; NS) (Fig. $2 D)$.

When proximal tubule cells were incubated for varying periods with dopamine $\left(10^{-5} \mathrm{M}\right)$, significant decreases in $\mathrm{AT}_{1}$ receptor mRNA expression were noted by $4 \mathrm{~h}$, and receptor ex-
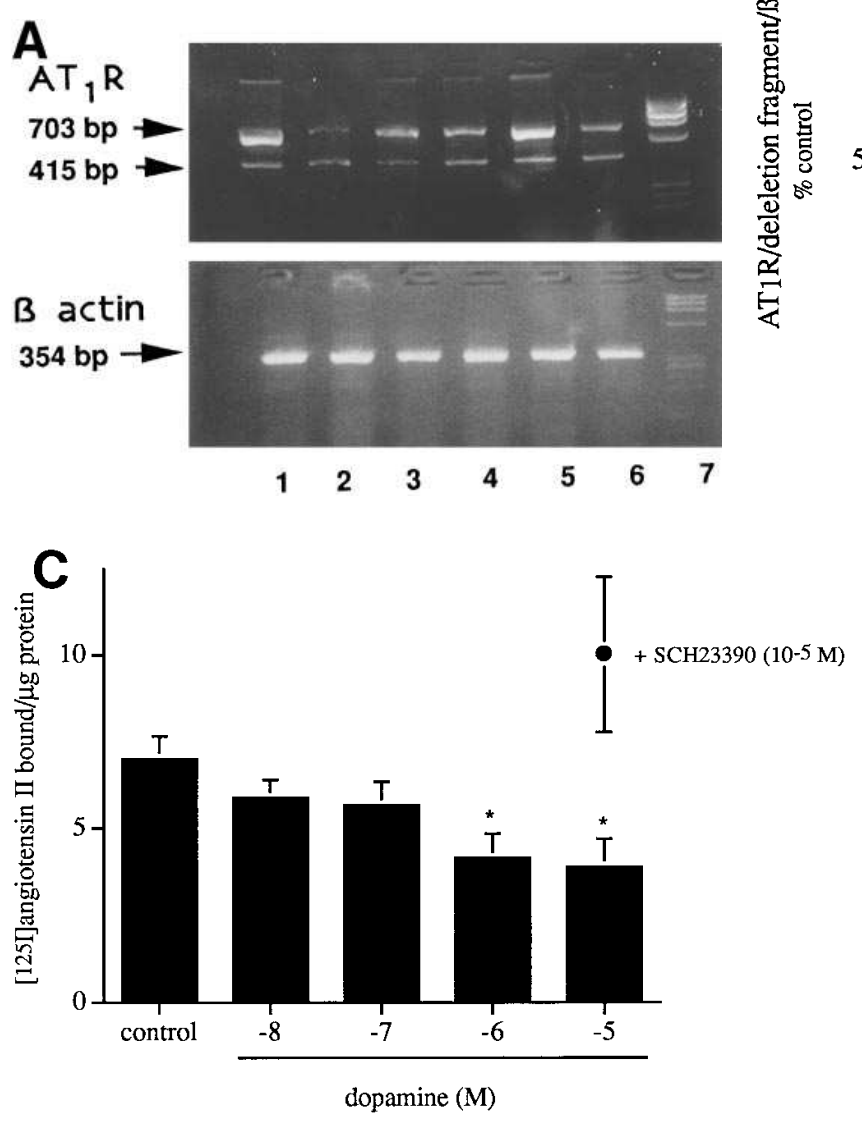
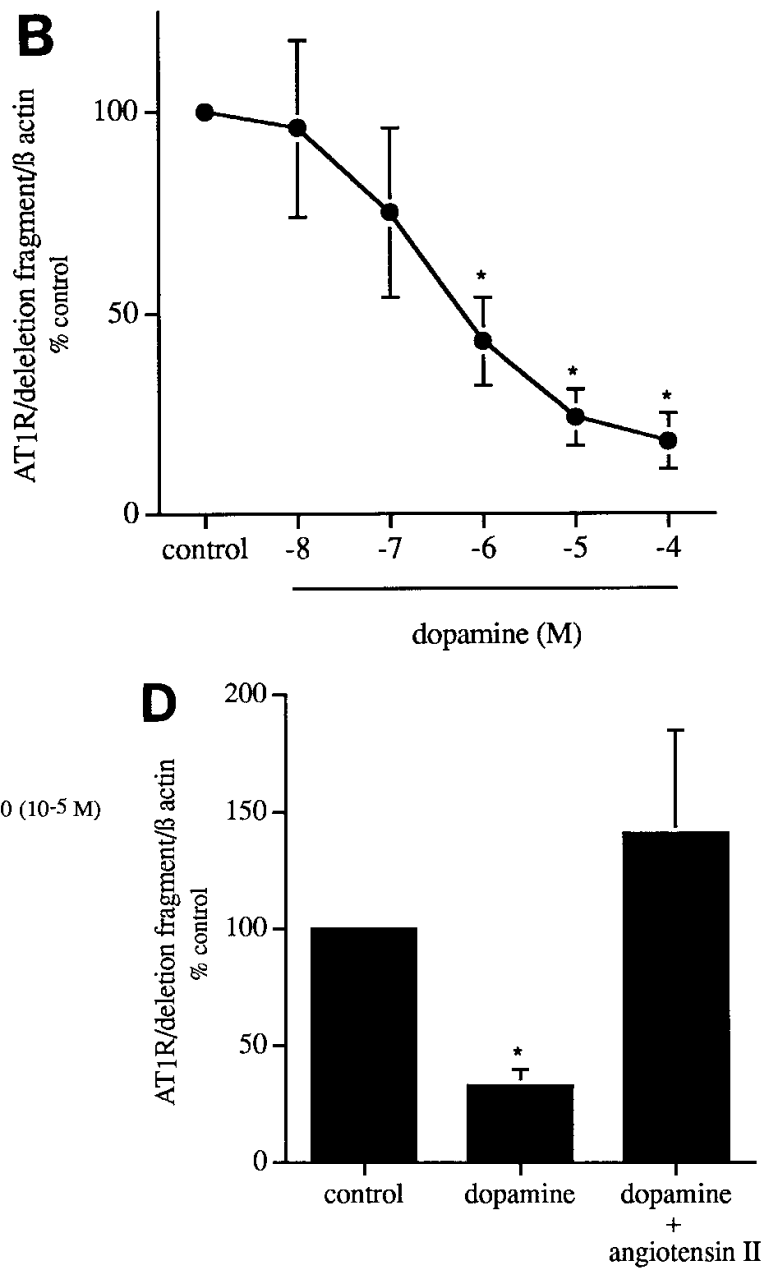

Figure 2. (A) Effect of dopamine on RT-PCR amplification of $\mathrm{AT}_{1} \mathrm{R}$ mRNA in SV40 immortalized rabbit proximal tubule cells. Agents were administered to quiescent cells for $4 \mathrm{~h}$ and then RNA was harvested. $100 \mathrm{pg}$ of cRNA of an MscI/MscI deletion fragment of rabbit $\mathrm{AT}_{1} \mathrm{R}$ was added to $10 \mu \mathrm{g}$ of total RNA and reversed transcribed. After reverse transcription, PCR was carried out for $35 \mathrm{cycles}$ at $95^{\circ} \mathrm{C}$ for $20 \mathrm{~s}, 55^{\circ} \mathrm{C}$ for $30 \mathrm{~s}$, and $72^{\circ} \mathrm{C}$ for $90 \mathrm{~s}$ using primers as described in Methods. The amplified fragment of intact $\mathrm{AT}_{1} \mathrm{R}$ is $703 \mathrm{bp}$ and the MscI/MscI deletion is $415 \mathrm{bp}$. $\beta$-actin was amplified in parallel tubes and its amplified fragment is $354 \mathrm{bp}$. Lane 1, control; lane 2, dopamine $\left(10^{-5} \mathrm{M}\right)$; lane 3, dopamine $\left(10^{-5}\right.$ M) +SCH23390 $\left(10^{-5} \mathrm{M}\right)$; lane 4, SKF38393 $\left(10^{-5} \mathrm{M}\right)$; lane 5, dopamine $\left(10^{-5} \mathrm{M}\right)+$ Ang II $\left(10^{-9} \mathrm{M}\right)$; lane 6, L-DOPA $\left(10^{-4} \mathrm{M}\right)$; lane 7 , size markers. $(B)$ Quantitative PCR of $\mathrm{AT}_{1} \mathrm{R}$ mRNA in RPTC after $4 \mathrm{~h}$ incubation with the indicated concentration of dopamine. Results are expressed as percent of control values of cpm $\mathrm{AT}_{1} \mathrm{R} / \mathrm{cpm}$ deletion fragment/cpm $\beta$-actin $\times 10^{6} .(n=5 ; * P<0.05)(C)$ Specific ${ }^{125} \mathrm{I}$-Ang II binding in RPTC after dopamine incubation. Cells were incubated for $16 \mathrm{~h}$ with the indicated concentration of dopamine and specific binding of $0.1 \mathrm{nM}$ ${ }^{125} \mathrm{I}$-Ang II was determined as described in Methods. Also indicated is specific ${ }^{125} \mathrm{I}$-Ang II after preincubation with dopamine $\left(10^{-5}\right)+\mathrm{SCH} 23390$ $\left(10^{-5}\right)$. $\left(n=5-8 ; * P<0.01\right.$ compared to control) $(D)$ Effect of angiotensin II upon dopamine-mediated decrease in AT ${ }_{1} \mathrm{R}$ mRNA in RPTC. Cells were incubated for $4 \mathrm{~h}$ with $10^{-5} \mathrm{M}$ dopamine $\left(n=10 ; P<0.005\right.$ compared with control) or with $10^{-5} \mathrm{M}$ dopamine $+10^{-9} \mathrm{M}$ angiotensin II $(n=8$; NS compared with control). 
pression was inhibited for at least $48 \mathrm{~h}$ in response to continuous incubation with dopamine (Fig. 3).

Further experiments were designed to determine which dopamine receptor subtype(s) mediated the decrease in $\mathrm{AT}_{1}$ receptor expression in RPTC. When cells were incubated with the $\mathrm{DA}_{1}$ subtype agonist SKF38393 $\left(10^{-5} \mathrm{M}\right), \mathrm{AT}_{1}$ receptor mRNA levels significantly decreased $(35 \pm 5 \%$ of control; $n=$ 5; $P<0.005$ ) (Figs. $2 A$ and $4 A$ ). Similarly, simultaneous incubation with the $\mathrm{DA}_{1}$ specific antagonist, $\mathrm{SCH} 23390\left(10^{-5} \mathrm{M}\right)$, in the presence of dopamine, reversed dopamine's decrease in receptor mRNA levels (33 \pm 7 vs. $76 \pm 10 \%$ of control; $P<$ 0.025 ) and ${ }^{125} \mathrm{I}-\mathrm{Ang}$ II binding (Figs. $2 C$ and $4 A$ ). However, no reversal of dopamine inhibition of $\mathrm{AT}_{1}$ receptor mRNA expression was seen with the $\mathrm{DA}_{2}$-specific antagonist spiperone (12 $\pm 7 \%$ of control; $n=8$; NS compared with dopamine) or octoclothepin $(25 \pm 7 \%$ of control; $n=8$; NS compared with dopamine) (Fig. $4 \mathrm{~B}$ ).

To determine if endogenously produced dopamine would also inhibit $\mathrm{AT}_{1}$ receptor expression, RPTC were incubated with the dopamine precursor, L-DOPA. Incubation with L-DOPA $\left(10^{-4} \mathrm{M}\right)$ for $4 \mathrm{~h}$ decreased $\mathrm{AT}_{1}$ receptor mRNA levels by $59 \pm 8 \%\left(29 \pm 6 \mathrm{cpm} / \mathrm{cpm}\right.$ of mutant $\mathrm{AT}_{1} \mathrm{R} / \mathrm{cpm}$ of $\beta$-actin $\times 10^{6} ; n=8 ; P<0.01$ ) (Figs. $2 A$ and 5). This inhibition appeared to be mediated by endogenously produced dopamine since simultaneous incubation with the $\mathrm{L}$ aromatic amino acid decarboxylase inhibitor, carbidopa, prevented the L-DOPA inhibition $(-16 \pm 12 \%$ inhibition; $n=7$; NS compared to control). Similarly, simultaneous incubation with the $\mathrm{DA}_{1}$ receptor antagonist $\mathrm{SCH} 23390$ prevented the inhibition of $\mathrm{AT}_{1}$ receptor mRNA expression ( $18 \pm 11 \%$ inhibition; $n=8$; NS compared with control), indicating that, as with exogenously administered dopamine, this inhibitory effect was mediated by $\mathrm{DA}_{1}$ receptors.

In the proximal tubule $\mathrm{DA}_{1}$ receptors stimulate adenylate cyclase via coupling to $\mathrm{G}_{\mathrm{s}}$. In the cultured proximal tubule cells, addition of dopamine increased cAMP levels from $15 \pm 4$ $\mathrm{pmol} / \mathrm{ml}$ to $44 \pm 6 \mathrm{pmol} / \mathrm{ml}(n=4 ; P<0.025)$, which was inhib-

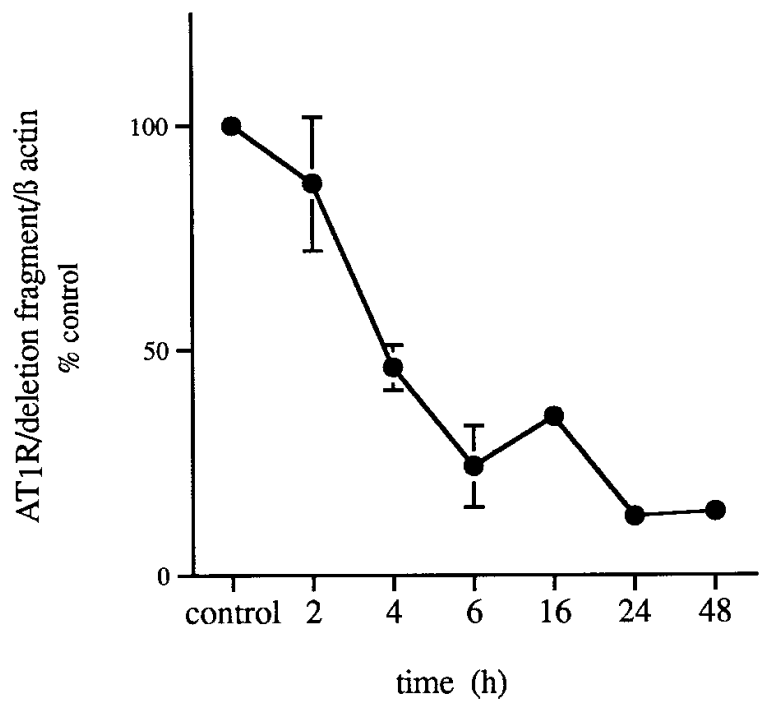

Figure 3. Time course of $\mathrm{AT}_{1} \mathrm{R}$ mRNA expression in RPTC in response to dopamine. Cells were incubated for the indicated time with $10^{-5} \mathrm{M}$ dopamine and quantitative PCR performed as described in Methods $(n=6 ; P<0.05)$.
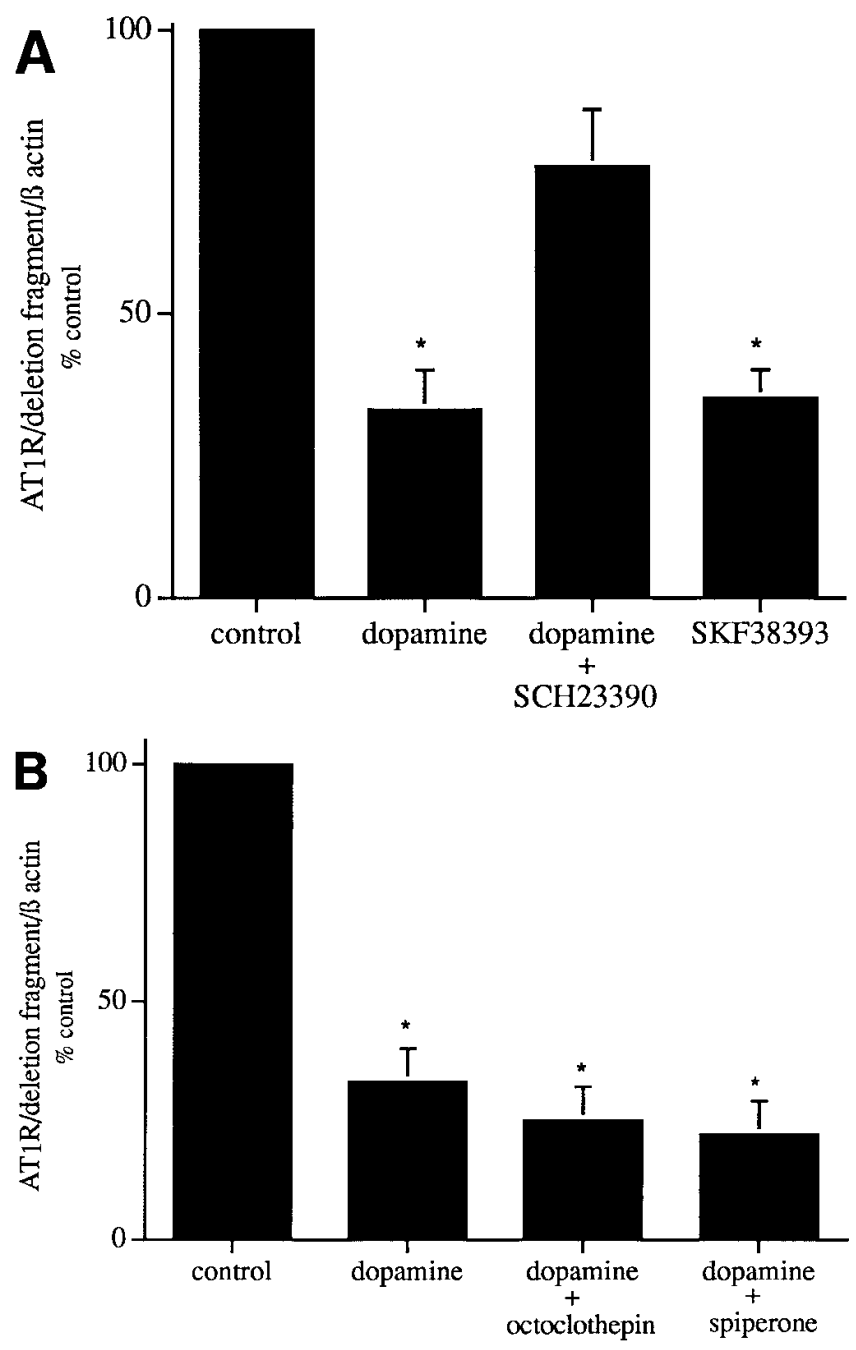

Figure 4. Effect of dopamine agonists and antagonists on $\mathrm{AT}_{1} \mathrm{R}$ mRNA expression in RPTC Cells were incubated with the indicated agents $\left(10^{-5} \mathrm{M}\right)$ for $4 \mathrm{~h}$ and quantitative PCR of $\mathrm{AT}_{1} \mathrm{R}$ mRNA determined. (A) $\mathrm{DA}_{1}$ agonist (SKF38393) or antagonist (SCH23390) $(n=$ 5 ; $* P<0.005$ compared to control). $(B) \mathrm{DA}_{2}$ antagonists $(n=8$; $* P<0.01$ compared with control).

ited by simultaneous administration of SCH23390 (5 $52 \mathrm{pmol} /$ ml) (Fig. 6). Similarly, L-DOPA increased cAMP levels to $28 \pm 2 \mathrm{pmol} / \mathrm{ml}(P<0.05)$.

To investigate whether dopamine-stimulated cAMP production was involved in decreased $\mathrm{AT}_{1}$ receptor expression, cultured proximal tubule cells were incubated with dopamine $\left(10^{-5} \mathrm{M}\right)$ with or without the adenylate cyclase inhibitor, dideoxyadenosine $\left(10^{-4} \mathrm{M}\right)(27)$ and $\mathrm{AT}_{1}$ receptor mRNA levels were assayed (Fig. 7). Dideoxyadenosine alone did not significantly alter receptor expression $(64 \pm 10 \%$ of control; $n=6$; NS). Dopamine alone decreased receptor expression to $27 \pm 6 \%$ of control $(P<0.0025)$; however, simultaneous administration of dideoxyadenosine reversed the dopamine-mediated inhibition of $\mathrm{AT}_{1}$ receptor expression $(80 \pm 24 \%$ of control; NS compared with control). Similar to our previous report (19), administration of the nonhydrolyzable analog of cAMP, dibutyrl-cAMP, decreased steady state levels of $\mathrm{AT}_{1}$ receptor mRNA levels to $32 \pm 6 \%$ of control $(n=6 ; P<0.005$ com- 


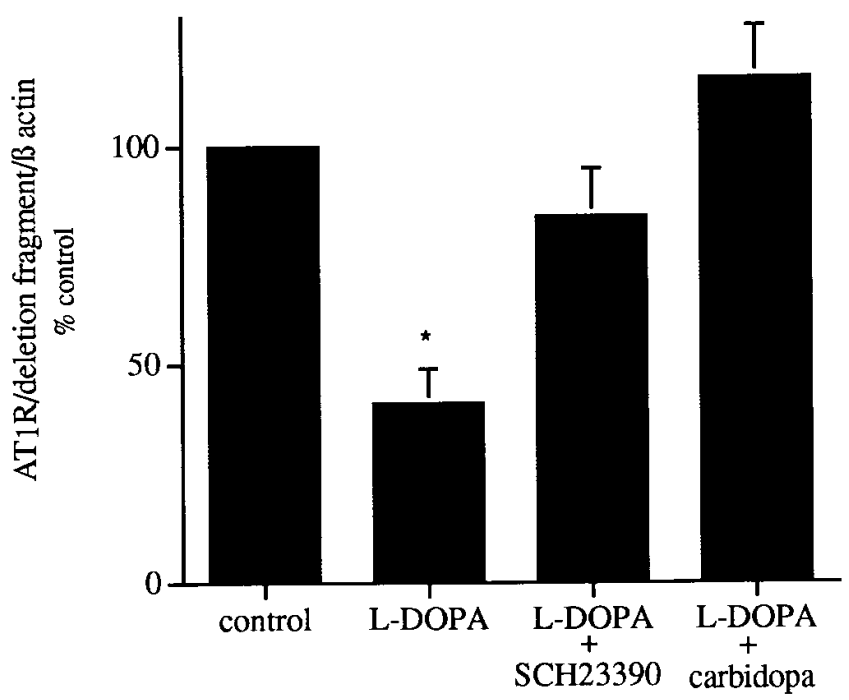

Figure 5. Effect of L-DOPA on $\mathrm{AT}_{1} \mathrm{R}$ mRNA expression in RPTC. Cells were incubated for $4 \mathrm{~h}$ with L-DOPA $\left(10^{-4} \mathrm{M}\right)$ with or without simultaneous incubation with the $\mathrm{DA}_{1}$ antagonist $\mathrm{SCH} 23390\left(10^{-5} \mathrm{M}\right)$ or the aromatic L-amino acid decarboxylase inhibitor, carbidopa $\left(10^{-4} \mathrm{M}\right) .(n=8 ; * P<0.01$ compared with control).

pared with control); simultaneous administration of dideoxyadenosine did not affect dibutyrl-cAMP-mediated receptor inhibition ( $28 \pm 5 \%$ of control; $P<0.0025$ ).

To determine whether the observed decrease in proximal tubule $\mathrm{AT}_{1}$ receptor expression also occurred in vivo, rats were treated with L-DOPA for 5 days. L-DOPA treatment did not affect body weight (control: $227 \pm 7$ grams; L-DOPA: $226 \pm 5$ grams; $n=9$; NS) or blood pressure (MAP: control: $78 \pm 3 \mathrm{mmHg}$; L-DOPA: $80 \pm 2 \mathrm{mmHg} ; n=9$; NS). The animals

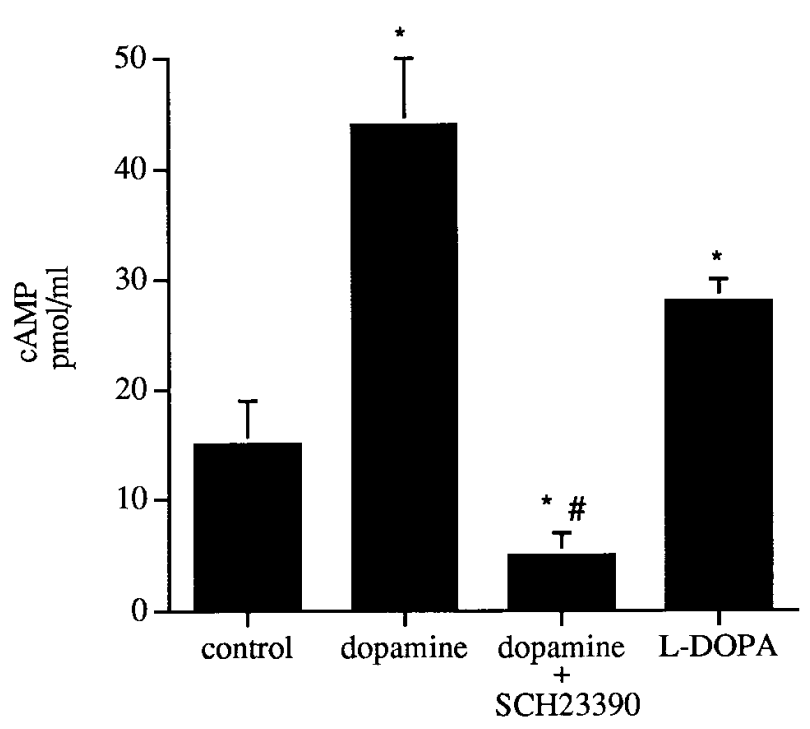

Figure 6. Effect of dopamine on cAMP production in RPTC. Cells were incubated for $10 \mathrm{~min}$ with the indicated agent $\left(10^{-5} \mathrm{M}\right.$ dopamine, $10^{-5} \mathrm{M} \mathrm{SCH} 23390,10^{-4} \mathrm{M}$ L-DOPA) in the presence of the phosphodiesterase inhibitor, isobutyl-methylxanthine $\left(10^{-4} \mathrm{M}\right)$ and cAMP was measured by RIA as described in Methods. $n=4$; $* P<$ 0.05 compared to control. were killed and proximal tubule RNA was extracted. As indicated in Fig. 8, compared with age matched controls, administration of L-DOPA decreased proximal tubule $\mathrm{AT}_{1}$ receptor mRNA levels by $80 \pm 5 \%$ ( $49 \pm 8$ vs. $9 \pm 2 \mathrm{cpm} / \mathrm{cpm}$ of mutant $\mathrm{AT}_{1} \mathrm{R} / \mathrm{cpm}$ of $\beta$-actin $\left.\times 10^{6} ; n=6 ; P<0.005\right)$. In separate animals, proximal tubule suspensions were prepared and ${ }^{125} \mathrm{I}$-Ang II binding was determined. L-DOPA treatment significantly decreased specific ${ }^{125} \mathrm{I}$-Ang II binding (control: 0.74 \pm 0.13 $\mathrm{fmol} / \mathrm{mg}$ pro. vs. $0.40 \pm 0.63 \mathrm{fmol} / \mathrm{mg}$ pro; $n=5 ; P<0.05)$.

\section{Discussion}

The major finding of this study is that dopamine decreased $\mathrm{AT}_{1}$ receptor mRNA expression and ${ }^{125}$ I-angiotensin II binding in cultured proximal tubule cells and in rat proximal tubules in vivo. The studies in the SV40 immortalized cultured rabbit proximal tubule cells indicated that the inhibition of $\mathrm{AT}_{1}$ receptor mRNA expression and ${ }^{125}$ I-angiotensin II binding was mediated by $\mathrm{DA}_{1}$ receptors. Dopamine stimulated increased cAMP production; furthermore, the adenylate cyclase inhibitor, dideoxyadenosine, prevented dopamine-mediated inhibition of $\mathrm{AT}_{1}$ receptor expression but did not prevent the inhibition induced by a cell permeant, nonhydrolyzable cAMP analog. Dopamine may inhibit $\mathrm{AT}_{1}$ receptor mRNA expression by increasing cAMP levels, in contradistinction to Ang II, which upregulates $\mathrm{AT}_{1}$ receptor expression in this nephron segment by decreasing cAMP levels (19).

In addition to the present investigations, studies in mesangial cells, vascular smooth muscle cells and adrenocortical cells have also noted that increasing intracellular cAMP levels decreases steady state $\mathrm{AT}_{1}$ receptor expression $(24,28,29)$. Since the $5^{\prime}$ promoter region of rat $\mathrm{AT}_{1}$ receptor expression is known to contain a cAMP response element, further studies will be required to determine whether cAMP decreases receptor expression by transcriptional and/or posttranscriptional mechanisms. In this regard, studies suggest that angiotensin II, which decreases $\mathrm{AT}_{1}$ receptor mRNA levels in vascular smooth muscle cells, appears to act through both transcriptional and post-transcriptional mechanisms (28).

Although both $\mathrm{DA}_{1}$ and $\mathrm{DA}_{2}$ receptors have been noted in kidney, $\mathrm{DA}_{1}$ receptors have been localized primarily to proximal tubules (30-32). $\mathrm{DA}_{1}$ receptor $\mathrm{mRNA}$ has been identified in microdissected rat proximal convoluted tubules (33) and in two cell lines with proximal tubule characteristics, OK cells and LLCPK-1 cells $(34,35) . \mathrm{DA}_{1}$ receptors in each cell type coupled to $G_{s}$, with activation of adenylate cyclase (34-36).

Ang II stimulates $\mathrm{Na}^{+} / \mathrm{H}^{+}$exchange in the proximal tubule at least in part by activation of $\mathrm{G}_{\mathrm{i}}$, leading to an inhibition of adenylate cyclase and a decrease in cAMP levels (4). Conversely, dopamine inhibits proximal tubule $\mathrm{Na}^{+} / \mathrm{H}^{+}$exchange at least in part by activation of $\mathrm{G}_{\mathrm{s}}$, leading to an increase in adenylate cyclase activity and cAMP levels (2, 12, 13, 35-38).

Ang II has also been shown to stimulate and dopamine to inhibit $\left[\mathrm{Na}^{+}\right] /\left[\mathrm{K}^{+}\right]$ATPase directly in proximal tubule. Sodium pump activation may require simultaneous activation of both $\mathrm{DA}_{1}$ and $\mathrm{DA}_{2}$ receptors in the proximal tubule (13). However, our studies with specific $\mathrm{DA}_{2}$ antagonists failed to indicate a role for a $\mathrm{DA}_{2}$ receptor mediated inhibition of $\mathrm{AT}_{1}$ receptor expression (12).

The presence of components of the renin-angiotensin system in proximal tubule suggests that locally produced angiotensin II may modulate proximal tubule function $(39,40)$. In 


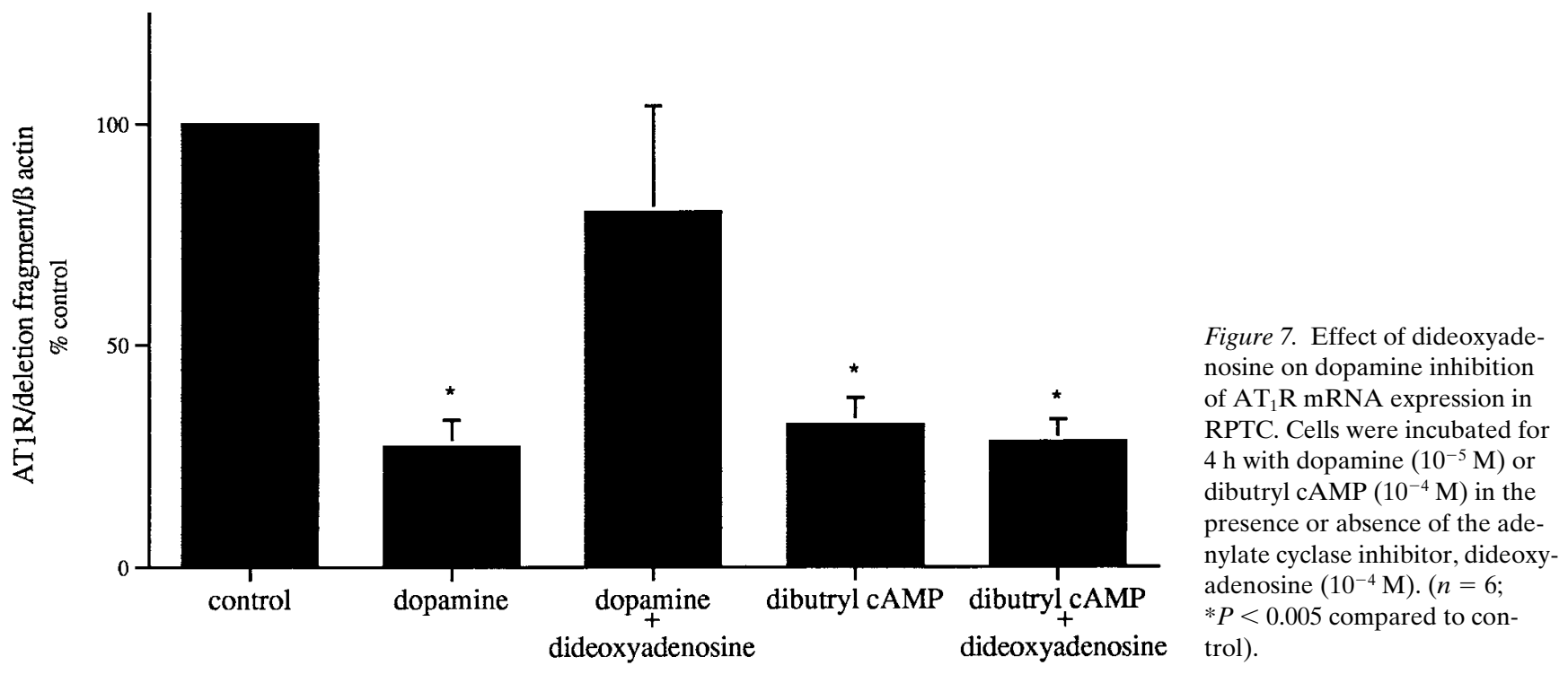

the kidney, angiotensinogen mRNA has been localized to the proximal tubule (41). In addition, renin and angiotensin converting enzyme have also been identified in the proximal tubule (4). Angiotensin II concentrations in rat proximal tubule lumen have been determined by free flow micropuncture and found to be in the range of $10^{-8} \mathrm{M}$, compared to concentrations in the range of $10^{-10} \mathrm{M}$ in systemic plasma $(39,42)$.

The proximal tubule is also the site of local dopamine production. Proximal tubules produce dopamine by uptake of L-DOPA ([-]-3-2[3,4-dihydroxyphenyl]-L-alanine) from tubular filtrate via a sodium dependent cotransport, followed by decarboxylation to dopamine by AADC (L-aromatic amino acid decarboxylase) (43). AADC is found in high concentrations in the proximal tubule $(13,44,45)$. Urinary dopamine concentrations exceed circulating levels, and the major source of urinary dopamine is thought to be from proximal tubule synthesis rather than from plasma or renal nerves, since inhibition of AADC decreases urinary excretion of dopamine. LLCPK-1 cells increase cAMP production in response to L-DOPA, which can be inhibited by either the $\mathrm{DA}_{1}$ antagonist, SCH23390 or the AADC inhibitor, carbidopa, suggesting that intracellular dopamine synthesis can contribute to $\mathrm{DA}_{1}$ mediated increases in cAMP (35).

In the present studies, the effect of dopamine or $\mathrm{DA}_{1}$ agonists upon $\mathrm{AT}_{1}$ receptor mRNA levels was mimicked by administration of L-DOPA and was blocked by simultaneous administration of either carbidopa or SCH23390. Furthermore, administration of L-DOPA to animals also decreased $\mathrm{AT}_{1}$ receptor mRNA levels in the proximal tubule, indicating a role for local dopamine production in regulating $\mathrm{AT}_{1}$ receptor mRNA expression.

Our previous studies indicated that salt depletion increased $\mathrm{AT}_{1}$ receptor mRNA and receptor density in proximal tubule (19). In rats, salt depletion also increased proximal tubule angiotensinogen mRNA levels (41), and a sodium deficient diet for $7 \mathrm{~d}$ increased renal angiotensin I and angiotensin II levels (41). Conversely, sodium loading increases urinary dopamine levels (31). The mechanism for this increased dopamine excretion has been attributed to increased DOPA concentrations in plasma and tubular lumen (46) and increased proximal tubule DOPA uptake via a sodium-dependent cotransport process (44). Therefore, volume expansion may serve to decrease
A $\mathrm{AT}_{1} \mathrm{R}$ 703 bp $\rightarrow$ 415 bp

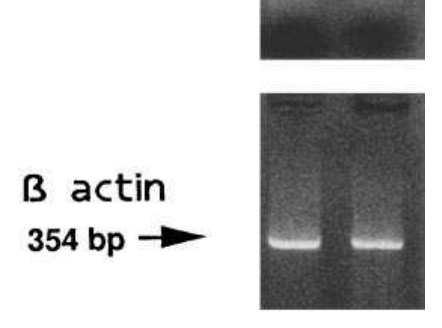
1

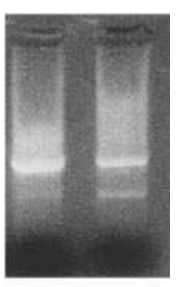

2

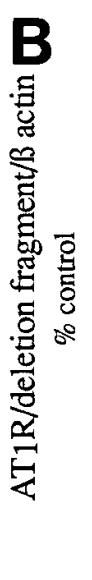

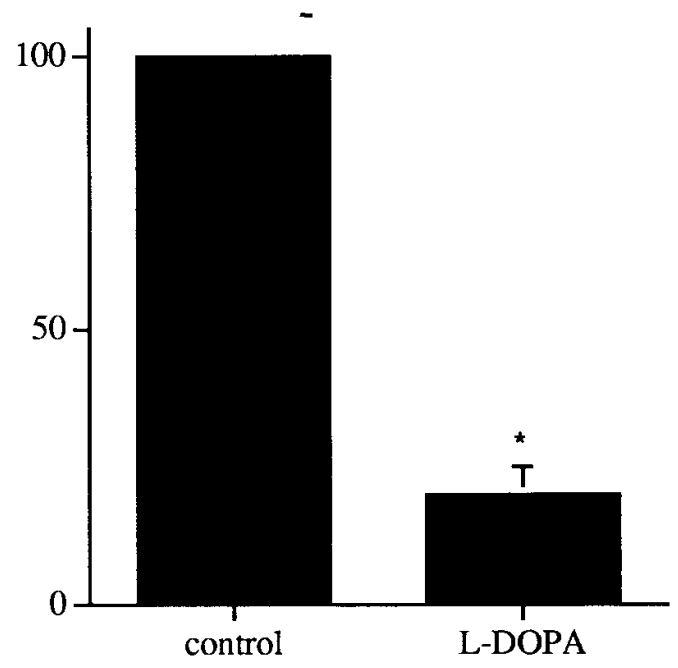

Figure 8. Effect of L-DOPA treatment on $\mathrm{AT}_{1} \mathrm{R}$ mRNA expression in rat proximal tubules. Sprague-Dawley rats were administered L-DOPA (2 $\mathrm{mg} / \mathrm{kg}$ per day) in the drinking water for $5 \mathrm{~d}$, proximal tubule RNA was harvested and RT-PCR was performed as described in Fig. 2. (A) Representative PCR reaction. Lane 1, control; lane 2 , L-DOPA. (B) Results of six experiments. $* P<0.005$ compared with control. 
proximal tubule $\mathrm{AT}_{1}$ receptor expression by decreasing local and/or systemic angiotensin II production and increasing proximal tubule dopamine production.

It is of interest that dopamine also interferes with angiotensin II-mediated aldosterone secretion in the adrenal, since it is known that sodium depletion and angiotensin II also upregulate adrenal angiotensin II receptors (47). Dopamine's effects have been attributed to hormonal regulation of the sodium-dependent modulation of adrenal angiotensin responsiveness (48). Although the question of whether dopamine alters adrenal angiotensin II receptor density has not yet been studied, these observations suggest that a mechanism by which dopamine may chronically modulate salt and water balance is by altering responsiveness to angiotensin II in the adrenal gland and the proximal tubule.

In two experimental models of hypertension, spontaneously hypertensive rats (SHR) and Dahl salt sensitive rats, defective coupling of dopamine to adenylate cyclase activation has been noted (49-53). In hypertensive humans, both defective renal dopamine production in response to salt loading and decreased proximal tubule responsiveness to dopamine have also been reported (54). Prehypertensive SHR express increased angiotensin II receptor density in proximal tubule and have increased proximal tubule reabsorption in response to angiotensin II infusion $(55,56)$. These findings suggest the possibility that in salt sensitive hypertension, defects in the proximal tubule dopaminergic system may prevent normal modulation of proximal tubule angiotensin II receptor density.

In summary, the present findings suggest that in addition to acute inhibition of proximal tubule volume reabsorption, dopamine may also serve to inhibit tonically $\mathrm{AT}_{1}$ receptor RNA expression and angiotensin II receptor density in the proximal tubule. Therefore, the balance between locally produced angiotensin II and dopamine may be important not only in the acute regulation of proximal reabsorption but also in the chronic resetting of proximal tubule responsiveness to angiotensin II stimulation.

\section{Acknowledgments}

R.C. Harris is a Clinical Investigator in the Career Development Program of the Veterans Administration.

This work was supported by funds from the Department of Veterans Affairs and by National Institutes of Health grants DK-38226 and DK-39261.

\section{References}

1. Cogan, M.G. 1990. Angiotensin II: a powerful controller of sodium transport in the early proximal tubule. Hypertension. 15:451-458.

2. Aperia, A. 1994. Dopamine action and metabolism in the kidney. Curr. Opin. Nephrol. Hypertens. 3:39-45.

3. Brown, G.P., and J.G. Douglas. 1982. Angiotensin II binding sites on isolated rat renal brush border membranes. Endocrinology. 111:1830-1836.

4. Brown, G.P., and J.G. Douglas. 1983. Angiotensin II-binding sites in rat and primate isolated renal tubular basolateral membranes. Endocrinology. 112: 2007-2014

5. Burns, K.D., T. Homma, and R.C. Harris. 1993. The intrarenal reninangiotensin system. Semin. Nephrol. 13:13-30.

6. Schuster, V.L., J.P. Kokko, and H.R. Jacobson. 1984. Angiotensin II directly stimulates sodium transport in rabbit proximal convoluted tubules. $J$. Clin. Invest. 73:507-515.

7. Liu, F-Y., and M.G. Cogan. 1988. Angiotensin II stimulation of hydrogen ion secretion in the rat early proximal tubule. Modes of action, mechanism, and kinetics. J. Clin. Invest. 82:601-607.

8. Burns, K.D., T. Inagami, and R.C. Harris. 1993. Cloning of a rabbit kid- ney cortex AT1 angiotensin II receptor that is present in proximal tubule epithelium. Am. J. Physiol. 264:F645-F654.

9. Xie, M.-H., F.-Y. Liu, P.C. Wong, P.B.M.W.H. Timmermans, and M.G Cogan. 1990. Proximal nephron and renal effects of DuP 753, a nonpeptide angiotensin II antagonist. Kidney Int. 38:473-479.

10. Chen, C.J., S. Apparsundarum, and M.F. Lokhandwala. 1991. Intrarenally produced angiotensin II opposes the natriuretic action of the dopamine-1 receptor agonist fenoldopam in rats. J. Pharm. Exp. Ther. 256:486-491.

11. Gesek, F.A., and A.C. Schoolwerth. 1991. Hormone responses of proximal $\mathrm{Na}(+)-\mathrm{H}(+)$ exchanger in spontaneously hypertensive rats. Am. J. Physiol. 261:F526-F536.

12. Aperia, A., U. Holtback, M.L. Syren, L.B. Svensson, J. Fryckstedt, and P. Greengard. 1994. Activation/deactivation of renal $\mathrm{Na}(+), \mathrm{K}(+)$-ATPase: a final common pathway for regulation of natriuresis. FASEB J. 8:436-439.

13. Bertorello, A., T. Hokfelt, M. Goldstein, and A. Aperia. 1988. Proximal tubule $\mathrm{Na}+-\mathrm{K}+$-ATPase activity is inhibited during high salt diet: evidence for DA-mediated effect. Am. J. Physiol. 254:F795-F801.

14. Felder, R.A., S. Kinoshita, A. Sidhu, K. Ohbu, and F.J. Kaskel. 1990. A renal dopamine-1 defect in two genetic models of hypertension. Am. J. Hypertens. 3:96S-99S.

15. Stier, C.T., H.D. Itskovitz, and Y.H. Chen. 1993. Urinary dopamine and sodium excretion in spontaneously hypertensive rats. Clin. Exp. Hypertens. 15: $105-123$.

16. Iwai, N., and T. Inagami. 1992. Identification of a candidate gene responsible for the high blood pressure of spontaneously hypertensive rats. J. Hypertens. 10:1155-1157.

17. Vinay, P., A. Gougoux, and G. Lemieux. 1981. Isolation of a pure suspension of rat proximal tubules. Am. J. Physiol. 241:F403-F411.

18. Harris, R.C., and T.O. Daniel, 1989. Epidermal growth factor binding, stimulation of phosphorylation and inhibition of gluconeogenesis in rat proximal tubule. J. Cell Physiol. 139:383-391.

19. Cheng, H-F., B.N. Becker, K.D. Burns, and R.C. Harris. 1995. Angiotensin II regulates its receptor sites in rabbit proximal tubule. J. Clin. Invest. 95: 2012-2019.

20. Harris, R.C. 1992. S6 kinase activity in proximal tubule cells. Evidence for activation by epidermal growth factor and angiotensin II in vitro and by contralateral nephrectomy in vivo. Am. J. Physiol. 263:F127-F134.

21. Chomczynski, P., and N. Sacchi. 1987. Single-step method of RNA isolation by acid guanidinium thiocyanate-phenol-chloroform extraction. Anal. Biochem. 162:156-159.

22. Cheng, H-F., K.D. Burns, and R.C. Harris. 1994. Reduced proximal tubule angiotensin II receptor expression in experimental diabetes mellitus. Kidney Int. 46:1603-1610.

23. Briggs, J.P., K. Todd-Turla, J.B. Schnermann, and P.D. Killen. 1993. Approach to the molecular basis of nephron heterogeneity: Application of reverse-transcription-polymerase chain reaction to dissected tubule segments. Semin. Nephrol. 13:2-12.

24. Makita, N., N. Iwai, T. Inagami, and K.F. Badr. 1992. Two distinct pathways in the down-regulation of type-1 angiotensin II receptor gene in rat glomerular mesangial cells. Biochem. Biophys. Res. Commun. 184:142-146.

25. Harris, R.C. 1989. Response of rat inner medullary collecting duct to epidermal growth factor. Am. J. Physiol. 256 (Renal Fluid and Electrol. 25) F1117-F1124.

26. Barnett, A., H.S. Ahn, W. Billard, E.H. Gold, J.D. Kohli, D. Glock, and L.I. Goldberg. 1986. Relative effects of SCH23390 and its analogs in three tests for $\mathrm{D}_{1} / \mathrm{DA}_{1}$ dopamine receptor antagonism. Eur. J. Pharmacol. 128:249-253.

27. Zenser, T.V., and R.W. Wannemacher, Jr. 1976. Inhibition of cholera toxin-stimulated intestinal epithelial cell adenylate cyclase by adenosine analogs. Proc. Soc. Exp. Biol. Med. 152:126-129.

28. Lassegue, B., R.W. Alexander, G. Nickenig, M. Clark, T.J. Murphy, and K.K. Griendling. 1995. Angiotensin II down-regulates the vascular smooth muscle AT1 receptor by transcriptional and post-transcriptional mechanisms: evidence for homologous and heterologous regulation. Mol. Pharmacol. 48: 601-609.

29. Bird, I.M., J.I. Mason, and W.E. Rainey. 1994. Regulation of type 1 angiotensin II receptor messenger ribonucleic acid expression in human adrenocortical carcinoma H295 cells. Endocrinology. 134:2468-2474.

30. Hegde, S.S., A. Ricci, F. Amenta, and M.F. Lokhandwala. 1989. Evidence from functional and autoradiographic studies for the presence of tubular dopamine-1 receptors and their involvement in the renal effects of fenoldopam. J. Pharmacol. Exp. Ther. 251:1237-1245.

31. Lokhandwala, M.F., and F. Amenta. 1991. Anatomical distribution and function of dopamine receptors in the kidney. FASEB J. 5:3023-3030.

32. Huo, T., and D.P. Healy. 1989. Autoradiographic localization of dopamine $\mathrm{DA}_{1}$ receptors in rat kidney with $\left[{ }^{3} \mathrm{H}\right] \mathrm{Sch} 23390$. Am J. Physiol. 257:F414F423.

33. Yamaguchi, I., P.A. Jose, M.M. Mouradian, L.M. Canessa, F.J. Monsma, Jr., D.R. Sibley, K. Takeyasu, and R.A. Felder. 1993. Expression of dopamine D1A receptor gene in proximal tubule of rat kidneys. Am. J. Physiol. 264:F280-F285.

34. Nash, S.R., N. Godinot, and M.G. Caron. 1993. Cloning and characterization of the opossum kidney cell D1 dopamine receptor: expression of identi- 
cal D1A and D1B dopamine receptor mRNAs in opossum kidney and brain. Mol. Pharm. 44:918-925.

35. Grenader, A., and D.P. Healy. 1991. Locally formed dopamine stimulates cAMP accumulation in LLC-PK1 cells via a DA1 dopamine receptor. Am. J. Physiol. 260:F906-F912.

36. Kinoshita, S., A. Sidhu, and R.A. Felder. 1989. Defective dopamine-1 receptor adenylate cyclase coupling in the proximal convoluted tubule from the spontaneously hypertensive rat. J. Clin. Invest. 84:1849-1856.

37. Felder, C.C., T. Campbell, F. Albrecht, and P.A. Jose. 1990. Dopamine inhibits $\mathrm{Na}+-\mathrm{H}+$ exchanger activity in renal BBMV by stimulation of adenylate cyclase. Am. J. Physiol. 259:F297-F303.

38. Cheng, L., P. Precht, D. Frank, and C.T. Liang. 1990. Dopamine stimulation of cAMP production in cultured opossum kidney cells. Am. J. Physiol. 258:F877-F882.

39. Seikaly, M.G., B.S. Arant, Jr., and F.D. Seney, Jr. 1990. Endogenous angiotensin concentrations in specific intrarenal fluid compartments in the rat. $J$. Clin. Invest. 86:1352-1357.

40. Braam, B., K.D. Mitchel, J. Fox, and L.G. Navar. 1993. Proximal tubular secretion of angiotensin II in rats. Am J. Physiol. 264:F891-898.

41. Ingelfinger, J.R., W. Min Zuo, E.A. Fon, K.E. Ellison, and V.J. Dzau. 1990. In situ hybridization evidence for angiotensinogen messenger RNA in the rat proximal tubule. J. Clin. Invest. 85:417-423.

42. Fox, J., S. Guan, A.A. Hymel, and L.G. Navar. 1992. Dietary Na and ACE inhibition effects on renal tissue angiotensin I and II and ACE activity in rats. Am J. Physiol. 262:F902-F909.

43. Lokhandwala, M.F., and S.S. Hegde. 1990. Cardiovascular dopamine receptors: role of renal dopamine and dopamine receptors in sodium excretion. Pharmacol. Toxicol. 66:237-243.

44. Baines, A.D., and W. Chan. 1980. Production of urine free dopamine from DOPA: a micropuncture study. Life Sci. 26:253-259.

45. Chan, Y.L. 1976. Cellular mechanisms of renal tubular transport of L-DOPA and its derivatives in the rat: micropuncture studies. J. Pharm. Exp. Ther. 199:17-24.

46. Carey, R.M., G.R. Van Loon, A.D. Baines, and E.M. Ortt. 1981. De- creased plasma and urinary dopamine during dietary sodium depletion in man. J. Clin. Endocrinol. Metab. 52:903-909.

47. Hauger, R.L., G. Aguilera, and K.J. Catt. 1978. Angiotensin II regulates its receptor sites in the adrenal glomerulosa. Nature (Lond.). 27:176-178.

48. Missale, C., C. Lombardi, R. DeCortis, M. Memo, M.O. Carruba, and P.C. Spano. 1989. Dopaminergic receptor mechanisms modulating the renin angiotensin system and aldosterone secretion: an overview. J. Cardiovasc. Pharmacol. 4 (Suppl 4):S29-S39.

49. Ohbu, K., F.J. Kaskel, S. Kinoshita, and R.A. Felder. 1995. Dopamine-1 receptors in the proximal convoluted tubule of Dahl rats: defective coupling to adenylate cyclase. Am. J. Physiol. 268:R231-R235.

50. Ohbu, K., and R.A. Felder. 1993. Nephron specificity of dopamine receptor-adenylyl cyclase defect in spontaneous hypertension. Am. J. Physiol. 264:F274-F279.

51. Chen, C.J., and M.F. Lokhandwala. 1992. An impairment of renal tubular DA-1 receptor function as the causative factor for diminished natriuresis to volume expansion in spontaneously hypertensive rats. Clin. Exp. Hypertension. 14:615-628.

52. Sidhu, A., P. Vachvanischsanong, P.A. Jose, and R.A. Felder. 1992. Persistent defective coupling of dopamine- 1 receptors to $\mathrm{G}$ proteins after solubilization from kidney proximal tubules of hypertensive rats. J. Clin. Invest. 89: 789-793.

53. Chen, C., R.E. Beach, and M.F. Lokhandwala. 1993. Dopamine fails to inhibit renal tubular sodium pump in hypertensive rats. Hypertension. 21:364 372

54. Clark, B.A., R.M. Rosa, F.H. Epstein, J.B. Young, and L. Landsberg. 1992. Altered dopaminergic responses in hypertension. Hypertension. 19:589594.

55. Matsushima, Y., M. Kawamura, and S. Akabane. 1988. Increases in renal angiotensin II content and tubular angiotensin II receptors in prehypertensive spontaneously hypertensive rats. J. Hypertension. 6:791-796.

56. Thomas, D., P.J. Harris, and T.O. Morgan. 1988. Altered responsiveness of proximal tubule fluid reabsorption of peritubular angiotensin II in spontaneously hypertensive rats. J. Hypertension. 6:407-410. 